\title{
Allogeneic Stem Cell Transplantation in Acute Myeloid Leukemia
}

\author{
Establishment of Indications on the Basis of Individual Risk Stratification
}

Axel Rolf Zander, Ulrike Bacher, Jürgen Finke

\begin{abstract}
SUMMARY
Introduction: Acute myeloid leukemia (AML) is a heterogeneous disorder with subtypes that differ considerably in morphology and in their underlying chromosomal and molecular aberrations, which, in turn, determine their prognosis. The establishment of the indications for allogeneic stem cell transplantation (SCT) therefore requires individualized risk stratification based on a combination of multiple diagnostic methods, including cytogenetic and molecular genetic studies, and immunophenotyping, as well as the sensitivity of the disease to chemotherapy.

Methods: This article surveys the current strategies for establishing the indications for SCT in AML on the basis of a selective review of the relevant literature in the Medline database.
\end{abstract}

Results: In patients with a high risk constellation-e.g., chromosome 7 anomalies, complex aberrations, or FLT3length mutations - there is an indication for SCT in first remission. The balanced translocations $\mathrm{t}(15 ; 17)$ and $\mathrm{t}(8 ; 21)$, and the inversion inv(16) are prognostically favorable and are thus not considered an indication for SCT in first remission. The establishment of indications for stem cell transplantation also depends on the residual leukemic cell burden (minimal residual disease, MRD) as determined by the quantitative polymerase chain reaction or by flow cytometry, as well as an insufficient response to induction chemotherapy. Reduced-dose conditioning, a new technique that lessens acute toxicity, has been found to be associated with a $30 \%$ to over $50 \%$ two-year survival rate when used in the treatment of chemotherapeutically unresponsive or relapsing AML.

Discussion: The indications for allogeneic SCT in AML should be further refined by more investigation in large studies.

Dtsch Arztebl Int 2008; 105(39): 663-9 DOI: 10.3238/arztebl.2008.0663

Key words: stem cell therapy, myelopathy, leukemia treatment, molecular medicine, indications

Onkologisches Zentrum, Klinik für Stammzelltransplantation, Universität Hamburg: Prof. Dr. med. Dr. h. c. Zander, PD. Dr. med. Bacher

Abteilung für Hämatologie/Onkologie, Universität Freiburg: Prof. Dr. med. Finke
1 cute myeloid leukemia (AML) occurs with an $\triangle$ annual incidence of 4 per 100000 persons in the western world. The median age at disease onset is 63 years with an increase in the incidence to about 15 per 100000 in over 65 -year-olds. Five-year survival is $25 \%$ to $35 \%$ in all patients, but diverges considerably depending on genetic subgroup and further risk factors (1). Intensive chemotherapy is sufficient for some patients; if there is a high risk of relapse, the indication for allogeneic stem cell transplantation (SCT) — from bone marrow, peripheral stem cells, or meanwhile also cord blood-is established.

The indication for allogeneic transplantation in acute leukemia is currently the subject of sometimes contentious debate following publication of a report by the Institute for Quality and Efficiency in Health Care (IQWiG). The present authors, who work in the field of allogeneic stem cell transplantation, take a critical view of some aspects of this report and, taking AML as an example, would like to describe in the form of an overview how complex the decision process for transplantation is and what criteria are relevant. A further aim is to present the impulses provided by molecular research for optimizing this indication.

Further changes have arisen through the concept of dose-reduced conditioning which both significantly reduces the toxicity of allogeneic SCT and allows its use in elderly patients or when concomitant diseases are present (1). A lower degree of tumor reduction is accepted in attenuated conditioning chemotherapy/radiotherapy, with higher priority being assigned to the immune effect of the transplantation against the leukemia.

To understand the complexity of establishing the indication for allogeneic transplantation in AML, it is first necessary to describe the heterogeneity of this condition on the basis of very different, genetically defined subgroups (1). $55 \%$ of the patients have a wide variety of aberrations at the chromosomal level. These range from structural changes such as balanced translocations, to numerical changes. Each of these is associated with a different relapse rate. For example, 5-year survival in acute promyelocytic leukemia (APL) with the translocation $\mathrm{t}(15 ; 17)(\mathrm{q} 22 ; \mathrm{q} 21)$ characterized by fusion of the PML (promelocytic leukemia) and RARA (retinoic acid receptor alpha) genes is more than $80 \%$, in contrast to scally significant mutations are also identifiable by molecular studies in more than $80 \%$ of cases in the $45 \%$ of patients without chromosomal aberrations (e2). 
The detection of the genetically determined risk constellations in all patients with acute myeloid leukemia is only possible thanks to the further development and use of a broad range of hematological diagnostic techniques. Cytomorphology, immunophenotyping, as well as cytogenetics and molecular genetics are some examples. Sensitive detection of the residual leukemia cell burden below the microscopic detection limit (minimal residual disease diagnosis) with the polymerase chain reaction (PCR) and flow cytometry allows early detection of relapse (2-5). Further biological factors are of importance: The prognosis is better in de novo AML (i.e., without previous chemotherapy or hematological disease) than in secondary AML after myelodysplastic syndrome (MDS) or in therapy-associated AML after chemo-/radiotherapy.

Numerous factors therefore influence survival and relapse probability in AML. An improved understanding of these prognostic factors-i.e., of the parameters relevant for the therapeutic outcomes under clinical or hematological diagnostic aspects-makes it possible to adapt the intensity of therapy to the individual risk constellation: In patients with a high risk of relapse according to the genetic analysis findings, allogeneic transplantation proved significantly superior to all other therapeutic strategies in all large studies (6). Even when there is inadequate response to therapy or an increase in the MRD (minimal residual disease) parameters which represent the residual leukemic cell burden, an allogeneic stem cell transplantation from a related or unrelated donor is attempted in order to utilize the "graft-versus-leukemia effect" additively to the cytotoxic therapy. On the other hand, "overtherapy" is to be avoided in patients with a favorable prognosis (7) - great importance attaches to this aspect in view of the morbidity and mortality associated with allogeneic SCT. Furthermore, numerous other factors, such as the patient's general condition or donor-recipient compatibility, are considered when establishing the indication.

When establishing the indication for allogeneic SCT in AML, therefore, numerous individual factors have to be considered, from whose combination conclusions can be drawn regarding the individual risk profile. This results in complex requirements for leukemia diagnostics (8).

\section{Study topic and methods}

This article provides an overview of the strategies currently employed in establishing the indication for allogeneic SCT for AML in adults. It further indicates which criteria are to be regarded as relevant for this decision, especially in relation to the various methods of hematological diagnosis and the disease stage. This survey was based on controlled studies (when available) with larger case numbers which evaluated SCT outcomes as a function of the respective risk profiles (table1). Moreover, emphasis was placed on studies performed to assess the indication for SCT in relation to the individual hematological diagnostic methods. However, the scope of this review article does not allow a complete presentation of the relevant literature (box 1).

\section{Results \\ Indication for SCT based on cytogenetics}

The karyotype as the strongest prognostic factor in AML allows patients to be classified into 3 risk groups (9, e3): The prognostically most favorable group comprises acute promyelocyte leukemia with balanced translocation $\mathrm{t}(15 ; 17)$ or the PML-RA-RA fusion and the balanced translocations $t(8 ; 21) / A M L 1-E T O$ and inversion inv(16)/CBFB-MYH11. The intermediate prognostic group contains patients with normal karyotype or, for example, trisomy 8.

The third prognostically unfavorable group includes, among others, unbalanced karyotypes as well as anomalies of chromosomes 3 or 7 . Complex changes with at least 3 chromosomal aberrations in about $15 \%$ of all cases can almost never be brought to stable remission with conventional therapy (8, e4). Also included are 11q23/MLL rearrangements (e5), which occur with an increased incidence after treatment with topoisomerase II inhibitors like the cytostatic agent etoposide. All these prognostically unfavorable changes show high relapse rates-in some cases $>80 \%$ - and therefore represent an indication for allogeneic SCT (8).

In these prognostically unfavorable risk groups, a significant improvement in survival due to allogeneic SCT was observed across all study samples; no negative influence was observed in any large study. For example, in one prospective study performed by two European research teams (EORTC/GIMEMA), leukemia-free survival of patients from cytogenetically unfavorable prognostic groups that underwent allogeneic transplantation was $43 \%$. For patients who received high-dose chemotherapy with autologous stem cell transplantation, leukemia-free survival was $18 \%$ (6). It should be taken into account, however, that in this case ultimately only a small group of patients could be evaluated and that the principle of "biological randomization" applied in this case did not go uncriticized: Patients with a suitable related donor underwent allogeneic stem cell transplantation, whereas patients without a related donor received high-dose therapy with autologous stem cell transplantation. The mean follow-up in this study was 4 years after transplantation.

In therapy-induced or secondary AML, for example after myelodysplastic syndrome (MDS), prognostically unfavorable karyotypes are in relative terms more frequent than in de novo AML $(10,11$, e6). In a retrospective analysis, patients with advanced MDS or secondary AML were found to have a 3-year survival of $31 \%$ and a disease-free survival of $28 \%$, although with a high transplantation-associated mortality of $52 \%$ (12). Nevertheless, the prognosis in these patient populations is extremely unfavorable, and these outcomes are therefore to be regarded as a success. Newer concepts with dose-reduced conditioning which are currently in the trial stage (13, e7-8) are hoped to provide further improvements in terms of transplantation-related mortality. 
Selected studies for risk stratification and results of allogeneic stem cell transplantation in AML

\begin{tabular}{|c|c|c|c|c|c|}
\hline & Source & Study group & Study type & Patients & Results \\
\hline \multirow[t]{4}{*}{$\begin{array}{l}\text { Cytogenetic } \\
\text { risk groups } \\
\text { of AML }\end{array}$} & $\begin{array}{l}\text { Slovak et al. } \\
2000(\mathrm{e} 28)\end{array}$ & $\begin{array}{l}\text { Southwest Oncology } \\
\text { Group/ } \\
\text { Eastern Cooperative } \\
\text { Oncology Group Study }\end{array}$ & $\begin{array}{l}\text { Biologically randomized study } \\
\text { to compare allo-SCT in HLA- } \\
\text { identical related donor vs } \\
\text { consolidation/autologous SCT }\end{array}$ & $\begin{array}{l}609 \text { patients }<56 \\
\text { years with AML }\end{array}$ & $\begin{array}{l}\text { AML classified into three cytogenetic } \\
\text { prognostic groups: favorable }(n=121) \text {; } \\
\text { intermediate }(n=278) ; \text { unfavorable }(n=184) \\
\text { (not classifiable: } n=26) \\
\text { significant superiority of allo-SCT } \\
\text { in prognostically unfavorable karyotype } \\
(n=38)\end{array}$ \\
\hline & $\begin{array}{l}\text { Byrd et al. } 2002 \\
\text { (9) }\end{array}$ & $\begin{array}{l}\text { Cancer and Leukemia } \\
\text { Group B } \\
\text { (CALGB 8461) }\end{array}$ & $\begin{array}{l}\text { Randomized study } \\
\text { to compare } \\
\text { different conventional } \\
\text { consolidation strategies }\end{array}$ & $\begin{array}{l}1213 \text { patients with } \\
\text { de novo AML }\end{array}$ & $\begin{array}{l}\text { Classification of AML into three cytogenetic } \\
\text { prognostic groups: favorable, medium, } \\
\text { unfavorable prognostic group }\end{array}$ \\
\hline & $\begin{array}{l}\text { Haferlach et al. } \\
2003(e 29)\end{array}$ & $\begin{array}{l}\text { German AML } \\
\text { Cooperative Group } \\
\text { (AMLCG) }\end{array}$ & $\begin{array}{l}\text { Randomized study to compare } \\
\text { different conventional } \\
\text { postremission strategies } \\
\text { (2nd consolidation vs maintenance) }\end{array}$ & $\begin{array}{l}614 \text { patients with } \\
\text { de novo AML }\end{array}$ & $\begin{array}{l}\text { Morphological dysplasia not an independent } \\
\text { prognostic parameter } \\
\text { Independent prognostic parameters: } \\
\text { cytogenetic prognostic group, age, LDH }\end{array}$ \\
\hline & $\begin{array}{l}\text { Buchner et al. } \\
2004 \text { (8) }\end{array}$ & $\begin{array}{l}\text { German AML } \\
\text { Cooperative Group } \\
\text { (AMLCG) }\end{array}$ & $\begin{array}{l}\text { Randomized study to compare } \\
\text { different conventional } \\
\text { induction strategies and } \\
\text { postremission strategies } \\
\text { (2nd consolidation vs } \\
\text { maintenance) }\end{array}$ & $\begin{array}{l}\text { Two sequential } \\
\text { analyses: } 832 \text { and } \\
1094 \text { patients } \\
\text { (16-81 years) with } \\
\text { de novo or s-AML }\end{array}$ & $\begin{array}{l}\text { Independent risk factors: } \\
\text { cytogenetic prognostic group, age, LDH, } \\
\text { bone marrow blasts on day } 16 \\
\text { after start of therapy }\end{array}$ \\
\hline \multirow[t]{4}{*}{$\begin{array}{l}\text { Molecular } \\
\text { risk groups } \\
\text { of AML }\end{array}$} & $\begin{array}{l}\text { Falini et al. } 2005 \\
\text { (15) }\end{array}$ & $\begin{array}{l}\text { Perugia University, } \\
\text { Italy }\end{array}$ & Retrospective analysis & $\begin{array}{l}591 \text { patients } \\
\text { ( } 15-60 \text { years) with } \\
\text { de novo AML }\end{array}$ & $\begin{array}{l}\text { NPM1 mutations: } \\
-35 \% \text { of all de novo AML cases } \\
\text { - good response to therapy }\end{array}$ \\
\hline & $\begin{array}{l}\text { Baldus et al. } 2003 \\
\text { (19) }\end{array}$ & $\begin{array}{l}\text { Cancer and Leukemia } \\
\text { Group B (CALGB9621) }\end{array}$ & Retrospective analysis & $\begin{array}{l}86 \text { patients with } \\
\text { de novo AML and } \\
\text { normal karyotype }\end{array}$ & $\begin{array}{l}\text { BAALC expression: high expression: } \\
\text { negative prognostic factor with poorer } \\
\text { survival with normal karyotype }\end{array}$ \\
\hline & $\begin{array}{l}\text { Döhner et al. } \\
2002 \text { (e30) }\end{array}$ & $\begin{array}{l}\text { Acute Myeloid } \\
\text { Leukemia Study } \\
\text { Group UIm (AMLSG) }\end{array}$ & Retrospective analysis & $\begin{array}{l}525 \text { patients } \\
\text { with AML }\end{array}$ & $\begin{array}{l}\text { MLL-PTD: } \\
\text { - incidence: } 8 \% \text { of all patients } \\
\text { - significantly inferior survival }\end{array}$ \\
\hline & $\begin{array}{l}\text { Yanada et al. } 2005 \\
\text { (14) }\end{array}$ & $\begin{array}{l}\text { Nagoya University, } \\
\text { Japan }\end{array}$ & $\begin{array}{l}\text { Meta-analysis of } 4 \text { larger } \\
\text { studies 2001-2003 }\end{array}$ & $\begin{array}{l}1160 \text { patients } \\
\text { with AML }\end{array}$ & $\begin{array}{l}\text { Mutation in FT3 gene: } \\
\text { - significantly inferior survival }\end{array}$ \\
\hline $\begin{array}{l}\text { Allogeneic SCT } \\
\text { in certain } \\
\text { molecular } \\
\text { risk groups }\end{array}$ & $\begin{array}{l}\text { Bornhauser } \\
\text { et al. } 2007 \text { (16) }\end{array}$ & $\begin{array}{l}\text { German Study } \\
\text { Initiative AML (DSIL) }\end{array}$ & $\begin{array}{l}\text { Biologically randomized study } \\
\text { to compare allo-SCT in HLA- } \\
\text { identical related donor vs } \\
\text { autologous SCT/conventional } \\
\text { consolidation therapy }\end{array}$ & $\begin{array}{l}999 \text { patients with } \\
A M L \leq 60 \text { years }\end{array}$ & $\begin{array}{l}\text { Comparison allogeneic/autologous SCT vs } \\
\text { chemotherapy alone in } 175 \text { patients with } \\
\text { AML/FLT3-LM/ITD: both allogeneic and } \\
\text { autologous SCT significantly superior } \\
\text { to conventional therapy } \\
\text { (4-year survival: } 46 \% \text { vs } 21 \%)\end{array}$ \\
\hline $\begin{array}{l}\text { Allogeneic/autologous } \\
\text { SCT in MDS/s-AML }\end{array}$ & $\begin{array}{l}\text { de Witte et al. } \\
2000 \text { (12) }\end{array}$ & $\begin{array}{l}\text { European Group for } \\
\text { Blood and Marrow } \\
\text { Transplantation (EBMT) }\end{array}$ & $\begin{array}{l}\text { Retrospective analysis } \\
\text { to compare the results } \\
\text { of allogeneic SCT from } \\
\text { related and unrelated donor } \\
\text { and autologous SCT }\end{array}$ & $\begin{array}{l}1378 \text { patients with } \\
\text { advanced } \\
\text { MDS/s-AML }\end{array}$ & $\begin{array}{l}\text { Comparison allogeneic SCT ( } n=1180) \text { / } \\
\text { autologous SCT }(n=173) \\
\text { Allogeneic SCT: } 3 \text {-year survival: } 31 \% \text {; } \\
\text { disease-free survival: } 28 \% \\
\text { Autologous SCT: relapse rate: } 55 \%\end{array}$ \\
\hline \multirow[t]{3}{*}{$\begin{array}{l}\text { Allogeneic SCT with } \\
\text { dose-reduced } \\
\text { conditioning } \\
\text { in MDS/s-AML }\end{array}$} & $\begin{array}{l}\text { Kröger et al. } 2003 \\
\text { (13) }\end{array}$ & $\begin{array}{l}\text { German Cooperative } \\
\text { Transplant } \\
\text { Study Group }\end{array}$ & Retrospective analysis & $\begin{array}{l}37 \text { patients with } \\
\text { MDS/s-AML }\end{array}$ & $\begin{array}{l}\text { Allogeneic SCT with dose-reduced } \\
\text { conditioning: } \\
\text { - 3-year survival: } 39 \% \\
\text { - disease-free survival: } 38 \%\end{array}$ \\
\hline & $\begin{array}{l}\text { Platzbecker et al. } \\
2006 \text { (21) }\end{array}$ & Dresden University & Prospective analysis & $\begin{array}{l}26 \text { patients with } \mathrm{AML} \\
\text { with unfavorable } \\
\text { karyotype/ } \\
\text { nonresponders }\end{array}$ & $\begin{array}{l}\text { Allo-SCT with dose-reduced conditioning } \\
\text { at median interval of only } 40 \text { days } \\
\text { after diagnosis of AML } \\
>3 \text {-year survival } 61 \%\end{array}$ \\
\hline & $\begin{array}{l}\text { Marks et al. } \\
2008 \text { (e31) }\end{array}$ & $\begin{array}{l}\text { Freiburg and } \\
\text { Regensburg } \\
\text { Universities }\end{array}$ & Prospective analysis & $\begin{array}{l}81 \text { patients with AML } \\
\text { and MDS }\end{array}$ & $\begin{array}{l}\text { Allo-SCT with dose-reduced conditioning } \\
\text { (fludarabine, BCNU, melphalan): } \\
3 \text {-year survival } 42 \% \text { in } 61 \text { patients with } \\
\text { refractory AML }\end{array}$ \\
\hline $\begin{array}{l}\text { Allogeneic SCT } \\
\text { in therapy refractory } \\
\text { AML }\end{array}$ & $\begin{array}{l}\text { Schmid et al. } \\
2006(20)\end{array}$ & $\begin{array}{l}\text { Ludwig-Maximilians- } \\
\text { University Munich }\end{array}$ & Prospective analysis & $\begin{array}{l}103 \text { patients with } \\
\text { therapy refractory } A M L\end{array}$ & $\begin{array}{l}\text { Allo-SCT with dose-reduced conditioning } \\
\text { after sequential chemotherapy in } \\
\text { therapy refractory AML } \\
>1 \text {-year survival } 54 \%\end{array}$ \\
\hline AML relapse & $\begin{array}{l}\text { Breems et al. } \\
2005(23)\end{array}$ & $\begin{array}{l}\text { Dutch-Belgian Hemato- } \\
\text { Oncology Cooperative } \\
\text { Group; Swiss Group } \\
\text { for Clinical Cancer } \\
\text { Research Collaborative } \\
\text { Group }\end{array}$ & $\begin{array}{l}\text { Retrospective analysis to compare } \\
\text { different salvage therapy strategies } \\
\text { in AML relapse (chemotherapy/ } \\
\text { autologous SCT/allogeneic SCT/ } \\
\text { donor lymphocytes/ } \\
\text { immune therapy) }\end{array}$ & $\begin{array}{l}667 \text { patients in } \\
\text { AML relapse }\end{array}$ & $\begin{array}{l}\text { Risk stratification in relapse: prognosis } \\
\text { depending on interval since first diagnosis, } \\
\text { karyotype, age, previous SCT; } \\
\text { Allogeneic SCT as salvage strategy in } \\
109 \text { patients }>5 \text {-year survival } 26 \% \text { vs } 6 \% \text { to } 9 \% \\
\text { for autologous SCT/chemotherapy } \\
\text { in the unfavorable risk group; } \\
88 \% \text { vs } 33 \% \text { to } 55 \% \text { in the favorable } \\
\text { risk group }\end{array}$ \\
\hline
\end{tabular}

SCT, stem cell transplantation; AML, acute myeloid leukemia; s-AML, secondary AML; MDS, myelodysplastic syndrome; PCR, polymerase chain reaction; NPM1, nucleophosmin gene; BAALC, brain and acute leukemia, cytoplasmic gene $M L L-P T D$, partial tandem duplication in the mixed lineage leukemia gene de novo AML, without therapy association or previous hematological disease; LDH, lactate dehydrogenase 
BOX 1

\section{Literature search method}

- Basis of literature search: Medline database

- Search terms: "acute myeloid leukemia" (AML), "allogeneic stem cell transplantation" (SCT), "prognosis," "risk stratification," "cytogenetics," "karyotype," "molecular genetics," "polymerase chain reaction" (PCR), "immunophenotyping," "multiparameter flow cytometry," "mutation," "minimal residual disease" (MRD), "remission," "dose reduced conditioning" (RIC), "clinical trial," "relapse," "refractory."

- Emphasis of selective literature review:

- Selection of studies evaluating the indication for stem cell transplantation in dependence on the different hematological diagnostic methods (cytomorphology, cytogenetics, molecular genetics, and immune phenotyping) and minimal residual disease (MRD) (detection of residual leukemia burden during the disease course).

- Selection of multicenter studies with large case numbers or selection of studies with the largest possible sample sizes for highly specific research topics.

\section{BOX 2}

\section{Chromosomal anomalies in hematological neoplasias}

Numerical aberration:

Gain or loss of one or more whole chromosomes

\section{Structural aberration:}

Gain or loss of chromosome portions

Inversion:

Rotation of a chromosome segment within a chromosome by $180^{\circ}$

Balanced translocation:

Exchange of segments between two chromosomes without loss or gain of material

Reciprocal gene fusion:

Correlate of a balanced translocation at the molecular level by fusion of not usually adjacent gene portions mutations in the FLT3 gene (FLT3-LM; FLT3-ITDs) which lead to increased cell proliferation are found in about $40 \%$ of all patients with normal karyotype. They are associated with poor therapeutic response and high relapse rates (e9, e10). Prognostically favorable are mutations in the nucleophosmin (NPM1) gene. This mutation blocks the function of the NPM1 protein in a tumor suppressor pathway (15) which plays a regulatory role for cell proliferation.

In future, molecular studies in the normal karyotype subgroup may allow a more differentiated decision regarding stem cell transplantation. For example, patients with an FLT3 length mutation appear to benefit from an allogeneic stem cell transplantation because the prognosis is otherwise so unfavorable (16). If no FLT3 length mutation is present, and if an NPM1 mutation is detectable, then the prognosis is so favorable that SCT need not be performed in primary therapy. The same applies for isolated mutations in the CEBPA gene which are also to be regarded as prognostically favorable (17).

The combination of different molecular markers is also relevant. For example, the prognosis with simultaneous detection of NPM1 and FLT3 length mutations is much more unfavorable than with an isolated NPM1 mutation (17).

Nevertheless, the indication for allogeneic stem cell transplantation in FLT3-positive AML should be researched further in prospective studies, because it remains a matter of controversy in some quarters (18).

Other mutations are also of importance when there is a normal karyotype. High expression of the BAALC (brain and acute leukemia, cytoplasmic) gene (19, e 11) and mutations in the MLL gene (MLL-PTD) (e12) are also prognostically unfavorable (box 3 ).

\section{Indication for SCT based on therapeutic response and age}

In about $15 \%$ of all AML patients up to 60 years of age and in more than $50 \%$ of patients above 60 years of age, induction chemotherapy is ineffective (therapy refractoriness). In this situation, allogeneic SCT is therefore the only option offering a curative approach based on the graft-versus-leukemia effect. In the refractory situation, prospective controlled studies use the approach of dose-reduced conditioning, which achieved a 2-year survival of about $30 \%$ (20). Whether the results could be improved even further by the later administration of lymphocytes from the same donor (donor lymphocyte infusions) to reinforce the immune effect will have to be defined in controlled studies (20, e13). Performing the transplantation at an early stage, at the latest 2.5 months after the diagnosis, is another promising approach for refractory situations (21).

It is further to be considered that the prognosis for AML patients over 60 years of age is much less promising than in younger patients because of the more frequent presence of prognostically unfavorable cytogenetic and molecular aberrations and because of the poorer response to chemotherapy. The modification of the allogeneic therapeutic procedures, including the introduction of dosereduced conditioning in combination with improved 


\section{TABLE 2}

Classification of acute myeloid leukemia into prognostic groups based on cytogenetics and molecular mutations

\begin{tabular}{|c|c|}
\hline Prognostic group & Genetic subgroup \\
\hline Favorable prognostic group & $\begin{array}{l}\text { - } \mathrm{t}(15 ; 17) / P M L-R A R A \\
\text { - } \mathrm{t}(8 ; 21) / A M L-E T O \\
\text { : inv(16)CBFB-MYH11 } \\
\text { - isolated NPM1 mutations (normal karyotype) } \\
\text { - isolated CEPBA mutations (normal karyotype) }\end{array}$ \\
\hline Intermediate prognostic group & $\begin{array}{l}\text { - normal karyotype } \\
\text { - trisomy } 8\end{array}$ \\
\hline Unfavorable prognostic group & $\begin{array}{l}\text { - complex aberrations ( } \geq 3 \text { chrom. anomalies) } \\
\text { - monosomy } 7 \\
\text { - anomalies on chromosome } 3 \\
\text { - } \text { FLT3 length mutations (FLT3-LM/FLT3-ITD) } \\
\text { MLLD }\end{array}$ \\
\hline
\end{tabular}

GvHD (graft-versus-host disease) prophylactic strategies, also allow successful SCT in elderly patients (22).

\section{Increase in minimal residual disease parameters}

Quantitative PCR offers the highest possible sensitivity for MRD diagnosis during the disease course. Examples include the prognostically favorable balanced changes $\mathrm{t}(15 ; 17), \mathrm{t}(8 ; 21)$, and inv(16), whose fusion transcripts can be quantified with molecular methods based on the polymerase chain reaction (PCR) (e14, e15, 4, 5). Persisting evidence after therapy (4) and a smaller decrease in the fusion transcript (5) correlate significantly $(\mathrm{p}<0.0001)$ with a higher relapse rate. An increase in the corresponding molecular markers may precede the clinically overt relapse by 3 to 6 months and should therefore prompt the clinician to consider allogeneic SCT. However, quantitative PCR has so far only been established for some of the mutations, and validation as MRD parameter is not yet complete.

In about $95 \%$ of all AML patients, flow cytometry can detect a leukemia-associated aberrant immune phenotype with good suitability for MRD diagnosis (2). It has been demonstrated in numerous studies that persistence or repeat detection of the aberrant immune phenotype after therapy correlates with an unfavorable prognosis. The value of MRD diagnosis based on immune phenotyping for therapy planning, however, certainly requires further study-based evaluation (3, e16, e17).

\section{Overt relapse}

Although the prognosis is generally poorer in relapse than for de novo AML, the karyotype also has an independent prognostic significance in this situation. For example, balanced changes such as $\mathrm{t}(8 ; 21)$ are also prognostically more favorable in this case than complex changes (23). The velocity of relapse development is also significant: Early relapses after less than 12 months are particularly unfavorable; second relapses are more critical than first relapses. Permanent remissions can rarely be achieved by purely conventional therapy in relapse, which is why allogeneic SCT should always be attempted. In relapse, this leads to a significant improvement in sur- vival compared to other options (23), even if the results are poorer because of higher transplant-related mortality (TRM) or higher relapse rates compared to transplantation in first remission (24).

\section{Discussion}

A steady increase in allogeneic transplantations has been observed in AML over the last 20 years. The basis for this development was created by dose-reduced conditioning (e18) and improved supportive therapeutic resources, as well as the extension of HLA typing by the use of molecular methods, the increased use of peripheral blood stem cells (e19, e20), and the expansion of voluntary donor databases.

On the other hand, improved genetic subclassification and the more sensitive MRD diagnosis also make it possible to define the prognosis more reliably and recognize relapses earlier (e21-25). In this prognostically favorable-admittedly numerically small—subgroup allogeneic SCT is not performed anymore in first complete remission, without thereby worsening the therapeutic outcome (7). In second remission-i.e., after relapse of the disease-allogeneic transplantation is, however, the only curative therapeutic alternative regardless of the initial risk status of the leukemia. The results of transplantation from unrelated donors are equivalent to those of sibling donors (e26).

This balancing act between achieving the greatest possible safety for patients with a high relapse risk by allogeneic SCT and identifying the patients who have an adequate curative chance on conventional therapy is only successful when the individual risk profile is closely considered. The results of cytogenetics and molecular genetics and MRD diagnosis after PCR are already integrated in all therapeutic AML studies established in Germany; the importance of immunophenotyping for MRD diagnosis still requires to be validated.

Nevertheless, many questions still remain unresolved. For example, the value of high-dose chemotherapy with autologous stem cell transplantation (which is used to improve hematopoietic regeneration) in AML has not yet been conclusively proven (16). There is also a continuing 


\section{BOX 3}

\section{Recurrent molecular mutations in AML}

FLT3 length mutations/internal tandem duplication (FLT3-LM/ITD):

Insertion of several hundred base pairs in the FLT3 gene which codes for a tyrosine kinase. The mutation leads to constitutive activation of this tyrosine kinase resulting in increased cell proliferation.

\section{NPM1 mutation:}

Mutation in the nucleophosmin gene which codes for the NPM1 protein. The mutation leads to an aberrant localization of the protein in the cytoplasm of the cells. The normal function of the NPM1 protein, which consists in the blockade of uninhibited cell proliferation, is thus disturbed.

\section{CEPBA mutation}

The CEPBA gene codes for a transcription factor. The mutation leads to a disturbance in the transcription process, thereby impeding the maturation of granulopoiesis.

\section{MLL-PTD:}

Partial tandem duplication and/or insertion in the MLL (mixed lineage leukemia) gene which has a control function in transcription processes. need to clarify the prognostic significance of numerous mutations, for example in the NRAS proto-oncogene. Within distinct genetic subgroups, considerable variabilities in the clinical course are observed which may be partly attributable to interaction with other mutations. The usually prognostically favorable APL may be considered as an example: In about $30 \%$ of the affected patients, a coincidence is found between FLT3 length mutations and a worsening of the prognosis. Further examples are the coincidence of FLT3 length mutations with NPM1 mutations or PML-RARA (e27).

The indication for allogeneic transplantation is therefore far from being conclusively defined. The further development of therapeutic and transplantation strategies for AML will continue to require a vigorous interaction with leukemia-specific diagnostics and its further development. The developments ongoing in the conventional therapeutic modalities, including the use of new molecular targeting substances, as well as the improvements introduced in allogeneic transplantation procedures with broader applicability including in older or comorbid patients are already providing, through differentiated use, successful therapy in more AML patients. Future studies should continue to aim at optimizing the criteria for allogeneic stem cell transplantation.

The authors thank Prof. Dr. Renate Arnold ( Charité University Hospital, Berlin), Prof. Dr. Dietrich Beelen (Essen University), Prof. Dr. Hermann Einsele (Würzburg University), Prof. Dr. Ernst Holler (Regensburg University), Prof. Dr. HansJoachim Kolb (Ludwig-Maximilians-University, Munich), Prof. Dr. Karin Kolbe (Mainz University), and Prof. Dr. Nicolaus Kröger (Hamburg University) for additions to this article.

\section{Conflict of interest statement}

The authors declare that no conflict of interest exists according to the guidelines of the International Committee of Medical Journal Editors.

Manuscript received on 13 June 2006, revised version accepted on 17 July 2007.

Translated from the original German by $\mathrm{mt}-\mathrm{g}$

\section{REFERENCES}

1. Estey E, Dohner H: Acute myeloid leukaemia. Lancet 2006; 368: 1894-907.

2. Feller $\mathrm{N}$, van der Pol MA, van SA, Weijers GW, Westra AH, Evertse BW et al.: MRD parameters using immunophenotypic detection methods are highly reliable in predicting survival in acute myeloid leukaemia. Leukemia 2004; 18: 1380-90.

3. Laane E, Derolf AR, Bjorklund E, Mazur J, Everaus H, Soderhall S et al.: The effect of allogeneic stem cell transplantation on outcome in younger acute myeloid leukemia patients with minimal residual disease detected by flow cytometry at the end of post-remission chemotherapy. Haematologica 2006; 91: 833-6.

4. Grimwade D, Jamal R, Goulden N, Kempski H, Mastrangelo S, Veys P: Salvage of patients with acute promyelocytic leukaemia with residual disease following ABMT performed in second CR using alltrans retinoic acid. Br J Haematol 1998; 103: 559-62.

5. Schnittger S, Weisser M, Schoch C, Hiddemann W, Haferlach T, Kern W: New score predicting for prognosis in PML-RARA+, AML1-ETO+, or CBFBMYH11+ acute myeloid leukemia based on quantification of fusion transcripts. Blood 2003; 102: 2746-55.

6. Suciu S, Mandelli F, de WT, Zittoun R, Gallo E, Labar B et al.: Allogeneic compared with autologous stem cell transplantation in the treatment of patients younger than 46 years with acute myeloid leukemia (AML) in first complete remission (CR1): an intention-totreat analysis of the EORTC/GIMEMAAML-10 trial. Blood 2003; 102: $1232-40$

7. de Labarthe A, Pautas C, Thomas X, de BS, Bordessoule D, Tilly H et al.: Allogeneic stem cell transplantation in second rather than first complete remission in selected patients with good-risk acute myeloid leukemia. Bone Marrow Transplant 2005; 35: 767-73.

8. Buchner T, Hiddemann W, Berdel WE, Wormann B, Schoch C, Fonatsch $C$ et al.: Subgroup specific therapy effects in AML: AMLCG data. Ann Hematol 2004; 83 (Suppl 1): S100-S101.

9. Byrd JC, Mrozek K, Dodge RK, Carroll AJ, Edwards CG, Arthur DC et al.: Pretreatment cytogenetic abnormalities are predictive of induction success, cumulative incidence of relapse, and overall survival in adult patients with de novo acute myeloid leukemia: results from Cancer and Leukemia Group B (CALGB 8461). Blood 2002; 100: 4325-36.

10. Messner HA: How good is allogeneic transplantation for high-risk patients with AML? Best Pract Res Clin Haematol 2006; 19: 329-32.

11. Larson RA: Is secondary leukemia an independent poor prognostic factor in acute myeloid leukemia? Best Pract Res Clin Haematol 2007; 20: 29-37.

12. de Witte T, Hermans J, Vossen J, Bacigalupo A, Meloni G, Jacobsen $\mathrm{N}$ et al.: Haematopoietic stem cell transplantation for patients with myelo-dysplastic syndromes and secondary acute myeloid leukaemias: a report on behalf of the Chronic Leukaemia Working Party of the European Group for Blood and Marrow Transplantation (EBMT). Br J Haematol 2000; 110: 620-30

13. Kröger N, Bornhauser M, Ehninger G, Schwerdtfeger R, Biersack H, Sayer HG et al.: Allogeneic stem cell transplantation after a fludarabine/busulfan-based reduced-intensity conditioning in patients with myelodysplastic syndrome or secondary acute myeloid leukemia. Ann Hematol 2003; 82: 336-42.

14. Yanada M, Matsuo K, Emi N, Naoe T: Efficacy of allogeneic hematopoietic stem cell transplantation depends on cytogenetic risk for acute myeloid leukemia in first disease remission: a metaanalysis. Cancer 2005; 103: 1652-8.

15. Falini B, Mecucci C, Tiacci E, Alcalay M, Rosati R, Pasqualucci L et al.: Cytoplasmic nucleophosmin in acute myelogenous leukemia with a normal karyotype. N Engl J Med 2005; 352: 254-66.

16. Bornhauser M, IIImer T, Schaich M, Soucek S, Ehninger G, Thiede C: Improved outcome after stem-cell transplantation in FLT3/ITDpositive AML. Blood 2007; 109: 2264-5.

17. Schlenk RF, Dohner K, Krauter J, Frohling S, Corbacioglu A, Bullinger $L$ et al.: Mutations and treatment outcome in cytogenetically normal acute myeloid leukemia. N Engl J Med 2008; 358: 1909-18. 
18. Gale RE, Hills R, Kottaridis PD, Srirangan S, Wheatley K, Burnett AK et al.: No evidence that FLT3 status should be considered as an indicator for transplantation in acute myeloid leukemia (AML): an analysis of 1135 patients, excluding acute promyelocytic leukemia, from the UK MRC AML10 and 12 trials. Blood 2005; 106: 3658-65.

19. Baldus CD, Tanner SM, Ruppert AS, Whitman SP, Archer KJ, Marcucci $G$ et al.: BAALC expression predicts clinical outcome of de novo acute myeloid leukemia patients with normal cytogenetics: a Cancer and Leukemia Group B Study. Blood 2003; 102: 1613-8.

20. Schmid C, Schleuning M, Schwerdtfeger R, Hertenstein B, MischakWeissinger $E$, Bunjes $D$ et al.: Long-term survival in refractory acute myeloid leukemia after sequential treatment with chemotherapy and reduced-intensity conditioning for allogeneic stem cell transplantation. Blood 2006; 108: 1092-9.

21. Platzbecker U, Thiede C, Fussel M, Geissler G, IIImer T, Mohr B et al.: Reduced intensity conditioning allows for up-front allogeneic hematopoietic stem cell transplantation after cytoreductive induction therapy in newly-diagnosed high-risk acute myeloid leukemia. Leukemia 2006; 20: 707-14.
22. Bertz H, Potthoff K, Finke J: Allogeneic stem-cell transplantation from related and unrelated donors in older patients with myeloid leukemia. J Clin Oncol 2003; 21: 1480-4.

23. Breems DA, Van Putten WL, Huijgens PC, Ossenkoppele GJ, Verhoef GE, Verdonck LF et al.: Prognostic index for adult patients with acute myeloid leukemia in first relapse. J Clin Oncol 2005; 23: 1969-78.

24. Bacigalupo A, Sormani MP, Lamparelli T, Gualandi F, Occhini D, Bregante $S$ et al.: Reducing transplant-related mortality after allogeneic hematopoietic stem cell transplantation. Haematologica 2004; 89: 1238-47.

\section{Corresponding author}

Prof. Dr. med. Dr. h. c. Axel R. Zander

Onkologisches Zentrum

Interdisziplinäre Klinik und Poliklinik für Stammzelltransplantation

Universitätsklinikum Hamburg-Eppendorf

Martinistr. 52

20246 Hamburg, Germany

zander@uke.de

Q www.aerzteblatt-international.de/ref3908 


\title{
REVIEW ARTICLE
}

\section{Allogeneic Stem Cell Transplantation in Acute Myeloid Leukemia}

\author{
Establishment of Indications on the Basis of Individual Risk Stratification
}

Axel Rolf Zander, Ulrike Bacher, Jürgen Finke

\section{E-REFERENCES}

e1. Bloomfield CD, Shuma C, Regal L et al.: Long-term survival of patients with acute myeloid leukemia: a third follow-up of the Fourth International Workshop on Chromosomes in Leukemia. Cancer 1997; 80: 2191-8.

e2. Marcucci G, Mrozek K, Bloomfield CD: Molecular heterogeneity and prognostic biomarkers in adults with acute myeloid leukemia and normal cytogenetics. Curr Opin Hematol 2005; 12: 68-75.

e3. Fröhling S, Schlenk RF, Kayser S, Morhardt M, Benner A, Döhner K, Döhner H, German-Austrian AML Study Group: Cytogenetics and age are major determinants of outcome in intensively treated acute myeloid leukmia patients older than 60 years: results from AMLSG trial AML H98-B. Blood 2006; 108: 3280-8.

e4. Schoch C, Haferlach T, Haase D et al.: Patients with de novo acute myeloid leukaemia and complex karyotype aberrations show a poor prognosis despite intensive treatment: a study of 90 patients. $\mathrm{Br} \mathrm{J}$ Haematol 2001; 112: 118-26.

e5. De Brakeleer M, Morel F, Le Bris MJ, Herry A, Douet-Guilbert N: The MLL gene and translocations involving chromosomal band 11q23 in acute leukemia. Anticancer Res 2005; 25: 1931-44.

e6. Larson RA: Etiology and management of therapy-related myeloid leukemia. Hematology. Am Soc Hematol Educ Program 2007; 2007: 453-9.

e7. Valcarcel D, Martino R, Caballero D et al.: Sustained remissions of high-risk acute myeloid leukemia and myelodysplastic syndrome after reduced-intensity conditioning allogeneic hematopoietic transplantation: chronic graft-versus-host disease is the strongest factor improving survival. J Clin Oncol 2007; 26: 577-84.

e8. Martino R, lacobelli S, Brand R et al.: Retrospective comparison of reduced-intensity conditioning and conventional high-dose conditioning for allogeneic hematopoietic stem cell transplantation using HLA-identical sibling donors in myelodysplastic syndromes. Blood 2006; 108: 836-46.

e9. Scholl S, Theuer C, Scheble V et al.: Clinical impact of nucleophosmin mutations and Flt3 internal tandem duplications in patients older than 60 years with acute myeloid leukemia. Eur J Haematol 2008; 80: 208-15.

e10. Thiede C, Steudel C, Mohr B et al.: Analysis of FLT3-activating mutations in 979 patients with acute myelogenous leukemia: association with FAB subtypes and identification of subgroups with poor prognosis. Blood 2002; 99: 4326-35.

e11. Mrozek K, Marcucci G, Paschka P, Whitman SP, Bloomfield CD: Clinical relevance of mutations and gene-expression changes in adult acute myeloid leukemia with normal cytogenetics: are we ready for a prognostically prioritized molecular classification? Blood 2007; 109: 431-48.

e12. Basecke J, Whelan JT, Griesinger F, Bertrand FE: The MLL partial tandem duplication in acute myeloid leukaemia. Br J Haematol 2006; 135: 438-49. e13. Schmid C, Labopin M, Nagler A et al.: Donor lymphocyte infusion in the treatment of first hematological relapse after allogeneic stemcell transplantation in adults with acute myeloid leukemia: a retrospective risk factors analysis and comparison with other strategies by the EBMT Acute Leukemia Working Party. J Clin Oncol 2007; 25: 4938-45.

e14. van der Reijden BA, Jansen JH: Diagnosis and monitoring of CBFBMYH11-positive acute myeloid leukemia by qualitative and quantitative RT-PCR. Methods Mol Med 2006; 125: 163-75.

e15. Elmaagacli AH, Beelen DW, Kroll M, Trzensky S, Stein C, Schaefer UW: Detection of CBFbeta/MYH11 fusion transcripts in patients with inv(16) acute myeloid leukemia after allogeneic bone marrow or peripheral blood progenitor cell transplantation. Bone Marrow Transplant 1998; 21: 159-66.

e16. Ruiz-Arguelles GJ, Fernandez-Lara D, Estrada-Gomez R et al.: Minimal residual disease testing in acute leukemia by flow cytometry immunophenotyping: prognostic significance. Lab Hematol 2007; 13: $22-6$.

e17. Buccisano F, Maurillo L, Gattei V et al.: The kinetics of reduction of minimal residual disease impacts on duration of response and survival of patients with acute myeloid leukemia. Leukemia 2006; 20: 1783-9.

e18. Tauro S, Craddock C, Peggs K et al.: Allogeneic stem-cell transplantation using a reduced-intensity conditioning regimen has the capacity to produce durable remissions and long-term diseasefree survival in patients with high-risk acute myeloid leukemia and myelodysplasia. J Clin Oncol 2005; 23: 9387-93.

e19. Ljungman P, Urbano-Ispizua A, Cavazzana-Calvo M et al.: Allogeneic and autologous transplantation for haematological diseases, solid tumours and immune disorders: definitions and current practice in Europe. Bone Marrow Transplant 2006; 37: 439-49.

e20. Gratwohl A, Baldomero H, Frauendorfer K, Urbano-Ispizua A, Niederwieser D: Results of the EBMT activity survey 2005 on haematopoietic stem cell transplantation: focus on increasing use of unrelated donors. Bone Marrow Transplant 2007; 39: 71-87.

e21. Elmaagacli AH: Molecular methods used for detection of minimal residual disease following hematopoietic stem cell transplantation in myeloid disorders. Methods Mol Med 2007; 134: 161-78.

e22. Santamaria C, Chillon MC, Fernandez C et al.: Using quantification of the PML-RARalpha transcript to stratify the risk of relapse in patients with acute promyelocytic leukemia. Haematologica 2007; 92: 315-22.

e23. Gorello P, Cazzaniga G, Alberti F et al.: Quantitative assessment of minimal residual disease in acute myeloid leukemia carrying nucleophosmin (NPM1) gene mutations. Leukemia 2006; 20: 1103-8.

e24. Grimwade D: The significance of minimal residual disease in patients with t(15;17). Best Pract Res Clin Haematol 2002; 15: $137-58$. 
e25. Perea G, Lasa A, Aventin A et al.: Prognostic value of minimal residual disease (MRD) in acute myeloid leukemia (AML) with favorable cytogenetics [t(8;21) and inv(16)]. Leukemia 2006; 20: 87-94.

e26. Sanz MA, Labopin M, Gorin NC et al.: Hematopoietic stem cell transplantation for adults with acute promyelocytic leukemia in the ATRA era: a survey of the European Cooperative Group for Blood and Marrow Transplantation. Bone Marrow Transplant 2007; 39: 461-9.

e27. Gilliland DG: FLT3-activating mutations in acute promyelocytic leukaemia: a rationale for risk-adapted therapy with FLT3 inhibitors. Best Pract Res Clin Haematol 2003; 16: 409-17.

e28. Slovak ML, Kopecky KJ, Cassileth PA et al.: Karyotypic analysis predicts outcome of preremission and postremission therapy in adult acute myeloid leukemia. A Southwest Oncology Group/Eastern Cooperative Oncology Group Study. Blood 2000; 96: 4075-83.

e29. Haferlach T, Schoch C, Löffler H et al.: Morphologic dysplasia in de novo acute myeloid leukemia (AML) is related to unfavorable cytogenetics but has no independent prognostic relevance under the conditions of intensive induction therapy. Results of a multiparameter analysis from the German AML Cooperative Group studies. J Clin Oncol 2003; 21: 256-65.

e30. Döhner K, Tobias K, Ulrich R et al.: Prognostic significance of partial tandem duplications of the MLL gene in adult patients 16 to 60 years old with acute myeloid leukemia and normal cytogenetics: a study of the Acute Myeloid Leukemia Study Group Ulm. J Clin Oncol 2002; 20: 3254-61.

e31. Marks R, Potthoff C, Hahn J et al.: Reduced-toxicity conditioning with fludarabine, BCNU, and melphalan in allogeneic hematopoietic cell transplantation: particular activity against advanced hematologic malignancies. Blood 2008; 112: 415-25. 